\title{
HUBUNGAN KEJADIAN MIOPIA DENGAN STATUS REFRAKSI ORANG TUA
}

\author{
Desi Utami Helisarah, Pindi Ayuni \\ ${ }^{1,2)}$ Program Studi Diploma Tiga Refraksi Optisi STIKes Dharma Husada \\ ${ }^{1)}$ d.c.utami.94@gmail.com \\ ${ }^{2)}$ pindiayuni1234@gmail.com
}

\begin{abstract}
Abstrak
Kelainan refraksi merupakan gangguan mata yang sering terjadi pada seseorang. Di Indonesia, Prevalensi kelainan refraksi menempati urutan pertama pada penyakit mata dan ditemukan jumlah penduduk kelainan refraksi hampir $25 \%$ populasi penduduk atau sekitar 55 juta jiwa. Penyebab kelainan refraksi miopia adalah multifaktorial, dapat terjadi dan dipengaruhi oleh beberapa faktor, antara lain usia, jenis kelamin, aktivitas dekat dengan atau tanpa layar, aktivitas diluar ruangan, riwayat genetik, dan lingkungan. Metode yang digunakan dalam penelitian ini yaitu literature review, bertujuan untuk mengetahui hubungan antara faktor keturunan dengan kejadian miopia, dengan melakukan proses analisisLiteratur sejumlah 5 jurnal.Hasil dari penelitian ini menunjukan hubungan yang signifikan terhadap faktor genetik yang mempengaruhi kejadian miopia. Meskipun ada perbedaan pada objek penelitian tetapi tidak mengurangi kesimpulan bahwa gen adalahfaktor yang kuat terhadap timbulnya miopia pada anak. Faktor genetik/herediter sangat erat sekali hubungannya terhadap kejadian miopia.

Kata kunci : Miopia, Genetik
\end{abstract}

\section{PENDAHULUAN}

Indera penglihatan merupakan bagian paling penting bagi upaya peningkatan kualitas sumber daya manusia yang dapat memberikan informasi secara visual. Mata dapat menjalankan fungsinya dengan baik karena didukung oleh bagian-bagian rumit dan sensitif seperti retina, media refrakta serta pembuluh darah. Kerusakan atau gangguan terhadap bagian-bagian tersebut dapat berakibat pada keterbatasan penglihatan dan kebutaan (Badan Pusat Statistik, 2013).

Keterbatasan penglihatan hingga kebutaan menyebabkan menurunnya informasi yang diterima bagi pemiliknya serta daya saing sumber daya manusia itu sendiri, sementara saat ini sumber daya manusia merupakan salah satu komponen pendukung yang penting dalam pembangunan nasional. Keterlambatan melakukan koreksi refraksi terutama pada anak usia sekolah akan sangat mempengaruhi kemampuan menyerap materi pembelajaran dan berkurangnya potensi untuk meningkatkan kecerdasan karena 30\% informasi diserap dengan melihat dan mendengar. Salah satu bentuk keterbatasan penglihatan adalah kelainan refraksi. (Direktorat pendidikan Luar Biasa, 2006)

Kelainan refraksi merupakan gangguan mata yang terjadi ketika mata tidak dapat melihat/fokus dengan jelas pada suatu area terbuka, sehingga pandangan menjadi kabur dan untuk kasus yang parah, gangguan ini dapat menjadikan visual impairment (melemahnya penglihatan). Di Indonesia, Prevalensi kelainan refraksi menempati urutan 
pertama pada penyakit mata. Penduduk yang mengalami kelainan refraksi hampir 25\% populasi penduduk atau sekitar 55 juta jiwa. Tiga jenis kelainan refraksi yang paling sering dijumpai yaitu miopia, hipermetropia, dan astigmatisme. (Ariestanti dkk, 2011).

Kelainan refraksi dapat terjadi dan dipengaruhi oleh beberapa faktor, antara lain usia, jenis kelamin, aktivitas dekat dengan atau tanpa layar, aktivitas diluar ruangan, riwayat genetik, dan lingkungan. Genetik memegang peranan besar pada miopia dan hipermetropia. Faktor genetik dan faktor lingkungan merupakan faktor risiko yang memegang peranan penting pada terjadinya kelainan refraksi. Berdasarkan hasil penelitianpenelitian sebelumnya, penyumbang angka kelainan refraksi tertinggi adalah Miopia.

Prevalensi miopia anak jauh lebih tinggi di negara-negara perkotaan Asia Timur (49,7$62,0 \%$ diantara anak-anak berusia 12 tahun), dibandingkan dengan negara lain (6,0-20,0\% di antara anak-anak berusia 12 tahun), Demikian pula, pada remaja dan dewasa muda, prevalensi miopia lebih tinggi di negara-negara Asia Timur (65,5-96,5\%) dibandingkan dengan negara lain (12,8-35,0\%). Namun, perbedaan geografis prevalensi miopia pada populasi yang lebih tua kurang dari pada populasi yang lebih muda. Tingkat prevalensi miopia pada orang dewasa di negara-negara perkotaan Asia Timur hanya sedikit lebih tinggi daripada di negara-negara Barat. (Ang, 2020)

Patofisiologi miopia adalah multifaktorial dan belum sepenuhnya
dipahami.Ada bukti bahwa banyak variasi genetik dan factor lingkungan dan gaya hidup memainkan peran penting dalam etiologi gangguan penglihata ini. dalam pengembangan miopia. Meskipun komponen genetik telah dipelajari secara luas, penelitian populasi manusia telah mengungkapkan prevalensi miopia yang sangat berbeda di antara populasi yang serupa secara genetik di lingkungan yang berbeda, menunjukkan bahwa pengembangan miopia dikendalikan oleh faktor lingkungan dan genetik. (Colvirtir dkk, 2019)

\section{METODE PENELITIAN}

Metode yang digunakan dalam penelitian ini yaitu literature review. Pencarian literature baik nasional maupun internasional yang dilakukan dengan menggunakan database EBSCO, ScienseDirect, dan Proquest. Pada tahap awal pencarian artikel jurnal diperoleh 5 jurnal dari 2015 sampai 2019 diketahui 2 jurnal nasional dan 3 jurnal internasional menggunakan kata kunci.

Metode analisis yang digunakan adalah dengan menggunakanLiterature review matrix yaitu dengan menggabungkan berbagai jurnal baik jurnal nasional maupun jurnal internasional yang bersifat relevan, mutakhir dan memadai, lalu setelah itu mencari kesamaan dan perbedaan dari berbagai jurnal tersebut kemudian dirumuskan dalam bentuk kerangka teori. 


\section{HASIL DAN PEMBAHASAN}

\section{A. HASIL}

\section{Tabel 1 Matrik Jurnal}

\begin{tabular}{|c|c|c|c|}
\hline $\begin{array}{c}\text { No. } \\
\text { Jurnal }\end{array}$ & $\begin{array}{c}\text { Nama, Judul, Tahun } \\
\text { Publikasi }\end{array}$ & Metode Penelitian & Hasil Penelitian \\
\hline 1. & $\begin{array}{l}\text { Nama Peneliti : } \\
\text { DamianCzepita, Mojsa } \\
\text { Artur, Maria Ustianowska, } \\
\text { Czepita Maciej, Lachowicz } \\
\text { Ewelina. } \\
\text { Judul Jurnal : } \\
\text { "Efek faktor genetik pada } \\
\text { terjadinya miopia" } \\
\text { Tahun Publikasi : } \\
29 \text { Mei } 2014\end{array}$ & $\begin{array}{l}\text { Sumber Data : } \\
\text { Sebanyak5.533 siswa diperiksa } \\
\text { (2.659 anak laki-laki dan } 2.874 \\
\text { anak perempuan, pada usia 6-18 } \\
\text { tahun, usia rata-rata } 11,9, \text { SD } \\
\text { 3,2). Yang diperiksa anak-anak, } \\
\text { siswa sekolah dasar dan } \\
\text { menengah, diperiksa di ruang } \\
\text { konsultasi sekolah. Siswa yang } \\
\text { diperiksa adalah ras Kaukasia } \\
\text { dan tinggal di sekitar Szczecin, } \\
\text { Polandia. } \\
\text { Teknik } \\
\text { Data : } \\
\text { Kuesioner. } \\
\text { Analisis data : } \\
\text { uji chi-sqared; nilai p <0,05 } \\
\text { dianggap signifikan secara } \\
\text { statistik. }\end{array}$ & $\begin{array}{l}\text { Ditemukan bahwa miopia } \\
\text { lebih sering terjadi pada } \\
\text { siswa yang ayahnya, ibu } \\
\text { atau saudara } \\
\text { kandung,memiliki riwayat } \\
\text { miopia. } \\
\text {. }\end{array}$ \\
\hline 2. & $\begin{array}{l}\text { Nama Peneliti : } \\
\text { Sepnita,Efhandi Nukman, } \\
\text { Eka Bebasari } \\
\text { Judul Jurnal : } \\
\text { "Hubungan antara faktor } \\
\text { keturunan, aktivitas melihat } \\
\text { dekat dan sikap pencegahan } \\
\text { mahasiswa “ } \\
\text { Tahun Publikasi : } \\
\text { Oktober } 2014\end{array}$ & $\begin{array}{l}\text { Sumber Data : } \\
\text { Miopia adalah kesalahan bias } \\
\text { dengan insiden antara } 50 \% \\
\text { sampai } 80,3 \% \text { di beberapa } \\
\text { rumah sakit di Indonesia. } \\
\text { Berdasarkan } \\
\text { OrganisasiKesehatan Dunia, } \\
\text { prevalensi miopia meningkat. } \\
\text { Prevalensi miopia di kalangan } \\
\text { mahasiswa kedokteran hampir } \\
\text { dua kali lebih tinggi dari } \\
\text { populasi umum. Faktor risiko } \\
\text { yang terkait dengan miopia } \\
\text { adalah faktor genetik/herediter, } \\
\text { aktivitas dekat kerja dan sikap } \\
\text { pencegahan. } \\
\text { Desain Penelitian : } \\
\text { Jenis penelitian ini adalah } \\
\text { analitik dengan desain } \\
\text { penelitian cross sectional. } \\
\text { Teknik Pengambilan Sampel : } \\
\text { Stratified random sampling. }\end{array}$ & $\begin{array}{l}\text { Penelitian ini } \\
\text { menunjukkan hubungan } \\
\text { yang signifikan untuk } \\
\text { faktor keturunan dengan } \\
\text { miopia . Tidak ada } \\
\text { hubungan statistik antara } \\
\text { membaca dan tugas } \\
\text { belajar,membaca untuk } \\
\text { kesenangan atau hobi, } \\
\text { menonton televisi, } \\
\text { menggunakan komputer } \\
\text { atau laptop. Tidak ada } \\
\text { hubungan antara sikap } \\
\text { pencegahan dengan } \\
\text { miopia. Didapatkan hasil } \\
\text { dari } 85 \text { responden didapati } \\
\text { bahwa } 37 \text { orang tidak } \\
\text { mengalami miopia dan } 48 \\
\text { orang yang mengalami } \\
\text { miopia, } 4 \text { orang } \\
\text { mempunyai kedua orang } \\
\text { tua yang mengalami } \\
\text { miopia. } 15 \text { rang lainnya } \\
\text { mempunyai salah satu } \\
\text { orang tua yang mengalami } \\
\text { mopia. Dan } 29 \text { orang } \\
\text { lainnya tidak memiliki } \\
\text { orang tua miopia. }\end{array}$ \\
\hline
\end{tabular}




\begin{tabular}{|c|c|c|c|}
\hline 3. & $\begin{array}{l}\text { Nama Peneliti : } \\
\text { Kattankulathur, Tamil } \\
\text { Nadu,India premaguhan } \\
\text { Judul Jurnal : } \\
\text { "Penyebabfaktor } \\
\text { kesalahan biaspada anak- } \\
\text { anak: keturunan atau } \\
\text { lingkungan" }\end{array}$ & $\begin{array}{l}\text { Sumber Data : } \\
\text { Sebanyak } 123 \text { siswa berusia } \\
\text { antara } 12 \text { dan } 13 \text { tahun disaring } \\
\text { dengan bantuan Ahli kacamata } \\
\text { di kelas. Dari } 46 \text { orang }(37,39 \%) \\
\text { dari mereka ditemukan memiliki } \\
\text { masalah dengan refractive error. } \\
\text { Desain Penelitian : } \\
\text { Analisis Univariat }\end{array}$ & $\begin{array}{l}\text { Dalam total } 123 \text { siswa } \\
\text { diperiksa, dari mereka } 46 \\
\text { pengembangan fisik, mental, } \\
\text { estetika dan spiritual } \\
(37,39 \%) \text { menderita } \\
\text { kesalahan bias. }\end{array}$ \\
\hline & $\begin{array}{l}\text { Tahun Publikasi : } \\
\text { Desember, } 2011\end{array}$ & $\begin{array}{l}\text { Teknik Pengambilan Sampel : } \\
\text { Stratified random sampling }\end{array}$ & \\
\hline 4. & & $\begin{array}{l}\text { Nama Peneliti : } \\
\text { Fatika Sari Hasibuan } \\
\text { Judul Jurnal : } \\
\text { "Hubungan Antara Faktor } \\
\text { keturunan, aktivitas melihat } \\
\text { dekat dan sikap pencegahan } \\
\text { mahasiswa fakultas kedokteran } \\
\text { Universitas Riau terhadap } \\
\text { kejadian miopia" } \\
\text { Tahun Publikasi : } \\
\text { Juli } 2017\end{array}$ & $\begin{array}{l}\text { Dari } 93 \text { orang mahasiswa, } 59 \\
\text { orang (63,4\%) mengalami } \\
\text { miopia, } 34 \text { orang }(36,6) \\
\text { normal. Secara keseluruhan, } \\
\text { para mahasiswa ini } \\
\text { menghabiskan waktu yang } \\
\text { bervariasi antara } \\
\text { mengerjakan tugas kuliah ( } 16 \\
\pm 10 \text { jam/minggu), menonton } \\
\text { tv ( } 12 \pm 11,7 \text { jam/minggu), } \\
\text { menggunakan computer ( } 15,4 \\
\pm 12,8 \text { jam/minggu). } \\
\text { Membaca untuk hobi lebih } \\
\text { sedikit dilakukan dari pada } \\
\text { untuk mengerjakan tugas } \\
\text { perkuliahan (6,5 } \pm 6,2 \\
\text { jam/minggu). } \\
\text { Selain itu, didapati bahwa } \\
\text { dari } 59 \text { orang mahasiswa } \\
\text { yang mengalami miopia, } \\
\text { orang mempunyai kedua } \\
\text { orang tua yang miopia. } 15 \\
\text { orang lainnya mempunyai } \\
\text { salah satu orang tua yang } \\
\text { mengalami miopia. Dan } 39 \\
\text { orang mahasiswa miopia } \\
\text { tidak memiliki orang tua } \\
\text { yang miopia } \\
\text { Anak yang kedua orang } \\
\text { tuanya mengalami miopia, } \\
\text { semuanya mengalami miopia, } \\
\text { dibandingkan dengan anak } \\
\text { yang salah satu orang tuanya } \\
\text { mengalami miopia ( } 78,9 \%) \\
\text { atau anak yang memiliki } \\
\text { orang tua yang tidak miopia } \\
\text { ( } 63,4 \%)\end{array}$ \\
\hline
\end{tabular}


5.

Nama Peneliti :
Mohamed Dirani,Matthew
Chamberlain, Sri N. Shekar,
Amirul FM Islam,. Pam
Garoufalis, Christine Y.
Chen, Robyn H. Guymer,
dan Paul N. Baird.
Judul Jurnal :
"Heritabilitas galat Refraktif
dan Biometik Mata : Studi
Kembar Gen dalam Miopia
(GEM)"
Tahun Publikasi :
November, 2005

Sumber Data :

Sebanyak 1.224 kembar (345

monozigot dan 267

pasangankembar dizigotik)

berusia antara 18 dan 88 tahun

diperiksa. Semua kembar menyelesaikan kuesioner yang terdiri dari riwayat medis, pendidikan, dan zigositas. Refraksi obyektif diukur pada semua kembar, dan pengukuran biometrik diperoleh dengan menggunakan interferometri koherensi parsial.

Teknik pengambilan

Data :

Kuesioner
Temuan dalam penelitian ini menunjukan bahwa miopia adalah penyakit mata yang kompleks yang disebabkan oleh faktor risiko genetik dan lingkungan.Telah diidentifikais dari studi korelasi keluarga dimana anak-anak dengan orang tua rabun berada pada risiko yang lebih besar dari pengembangan miopia daripada anakanak dengan orang tua non rabun.

\section{B. PEMBAHASAN}

Berdasarkan penelaahan pada jurnal 1 ditemukan bahwa miopia lebih sering terjad pada siswa yang ayah, ibu atau saudara kandung memiliki riwayat miopia. Menurut peneliti di jurnal satu, faktor keturunan adalah faktor paling penting yang terkait dengan miopia pada anak, dengan kontribusi independen yang lebih kecil dari pekerjaan dekat, prestasi sekolah yang lebih tinggi dan lebih sedikit waktu yang dihabiskan untuk melakukan kegiatan olahraga. Namun, peluang menjadi rabun untuk anak-anak tanpa orang tua rabun, dibandingkan dengan mereka yang memiliki satu atau dua orang tua rabun.

Hal ini diperkuat oleh hasil penelitian Saw et al Singapura. Para peneliti di jurnal tersebut telah membuktikan setelah memeriksa 153 anak-anak usia antara 6-12 tahun bahwa tingkat rata-rata perkembangan miopia untuk anak-anak dengan riwayat miopia orang tua adalah $-0,63 \mathrm{D}$ per tahun dibandingkan dengan $-0,42 \mathrm{D}$ per tahun untuk anak-anak, yang orang tuanya bukan rabun. Jurnal ini membahas mengenai keterkaitan antara ras dengan kelainan miopia berdasarkan hasil penelitian Lam et al. Setelah melakukan penelitian pada 7.560 anak-anak Cina dan Liang et al. Setelah melakukan studi pada 887 orang Taiwan menemukan efek orangtua yang kuat pada tingkat dan timbulnya miopia pada keturunan mereka. Dalam penelitian saat ini telah diamati, bahwa riwayat keluarga miopia mengarah pada pengurangan refraktif eror dan peningkatan panjang aksial bola mata. Dimensi mata lainnya seperti kelengkungan kornea, kedalaman ruang anterior, ketebalan lensa dan kedalaman ruang vitreous, berubah dalam skala yang lebih kecil .

Terdapat perbedaan objek penelitian antara jurnal 1 dan jurnal 2. Objek penelitian jurnal 2 adalah remaja, objek penelitian jurnal 1 adalah anak-anak. Dalam jurnal 2 
didapatkan hasil hubungan antara miopia dengan faktor keturunan pada mahasiswa Fakultas Kedokteran Universitas Riau. Dari 85 responden, 37 orang tidak mengalami miopia dan 48 orang yang mengalami miopia. 4 orang mempunyai kedua orang tua yang miopia. 15 orang lainnya mempunyai salah satu orang tua yang mengalami miopia dan 29 orang tidak memiliki orang tua yang miopia.

Hasil uji Chi-Square nilai $\mathrm{p}=0,001$ artinya terdapat hubungan bermakna antara faktor keturunan dengan miopia. Orang dengan riwayat miopia memiliki kemungkinan lebih besar untuk mengalami miopia daripada emetropia. Penelitian jurnal 2 diperkuat oleh hasil penelitian yang dilakukan oleh Melita Perty Arianti dimana dari 44 responden yang mengalami miopia, didapatkan 18 responden memiliki riwayat miopia di keluarga, sedangkan dari 26 responden yang tidak mengalami miopia, 3 orang memiliki riwayat miopia di keluarga dan didapatkan nilai p 0,010 yang didapat dengan uji Chi-Square.

Objek penelitian jurnal 3 sama dengan objek penelitian jurnal 1, yaitu anak-anak. Didapatkan hasil adanya hubungan yang signifikan antara kelainan refraksi dan riwayat penggunaan kacamata pada orang tua. Jika salah satu atau kedua orang tua mengenakan kacamata koreksi, maka anakanak mereka pasti memiliki masalah dalampenglihatan mereka. Anak-anak lain juga memiliki masalah dalam penglihatan, tetapi jumlah ini jauh lebih sedikit apabila orang tua mereka tidak memiliki kelainan refraksi.

Hasil penelitian ini diperkuat oleh penelitian yang dilakukan oleh Saw et al yang dalam penelitiannya ditemukan bahwa keluarga yang memiliki riwayat yang berhungan dengan kelainan refraksi maka anak mereka akan mengalami kelainan refraksi juga. Dalam hal ini faktor gen memiliki faktor yang sangat berpengaruh.

Hasil penelitian jurnal 4 memperkuat hasil penelitian jurnal 1, 2, dan 3, dimana faktor genetik mempengaruhi miopia pada anak. Objek penelitian jurnal 4 sama dengan jurnal 2, yaitu remaja. Didapatkan hasil, 59 orang mahasiswa yang mengalami miopia, 5 orang mempunyai kedua orang tua yang miopia, 15 orang lainnya mempunyai salah satu orang tua yang mengalami miopia dan 39 orang mahasiswa miopia tidak memiliki orang tua yang miopia. Konsisten dengan hasil penelitian sebelumnya bahwa ada faktor keturunan yang mendasari seseorang mengalami miopia. Hal ini cenderung mengikuti dose respons pattern. Dalam penelitian ini, anak yang kedua orang tuanya mengalami miopia, semuanya mengalami miopia dibandingkan dengan anak yang salah satu orang tuanya mengalami miopia $(78,9 \%)$ atau anak yang memiliki orang tua tidak miopia $(63,4 \%)$.

Pada penelitian di jurnal 5 hasil penelitiannya menggambarkan bahwa faktor genetik miopia pada anak tidak berpengaruh terhadap keturun kembar atau tidak. Hal ini menggambarkan bahwa faktor genetik lebih 
kepada efek genetik aditif penyumbang proporsi yang lebih besar dari varians dalam kesalahan refraksi, sedangkan varians dalam biometrik okular, terutama panjang aksial dijelaskan sebagian besar oleh efek genetik dominan, asal genetik miopia berasal dari beberapa sumber, termasuk studi hubungan keluarga di mana beberapa kasus miopia telah diidentifikasi untuk berbagai keparahan miopia, dan studi korelasi keluarga di mana anak-anak dengan orang tua rabun berada pada risiko yang lebih besar dari pengembangan miopia daripada anak-anak dengan orang tua non-rabun.

Penelitian lebih lanjut berdasarkan heritabilitas refraktif eror, termasuk miopia pada kembar, juga secara konsisten menunjukkan kemungkinan keterlibatan komponen genetik utama terhadap refraktif eror. Dari semua jenis kelainan refraksi, yang paling banyak dipelajari adalah miopia.Miopia adalah gangguan mata manusia yang paling umum di dunia, dampaknya terhadap kesehatan masyarakat dan ekonomi sangat besar. Sebuah studi di Eropa menemukan bahwa skor risiko genetik yang terdiri dari 26 varian genetik paling kuat terkait dengan miopia pada individu dengan pendidikan tingkat universitas.

Berdasarkan penelitian pada jurnal 1, 2, 3, 4 didapatkan hasil yang saling menguatkan bahwa faktor genetik sangat mempengaruhi kejadian miopia meskipun ada perbedaan pada objek penelitian tetapi tidak mengurangi faktor bahwa gen adalah yang kuat terhadap pewarisan miopia. Hal ini telah di buktikan oleh teori yang didapatkan dan menjelaskan bahwa genetik mempengaruhi miopia.

\section{KESIMPULAN}

1. Berdasarkan hasil kajian literatur dari beberapa jurnal dan hasil penelitian, menunjukan bahwa faktor genetik/herediter sangat erat sekali hubungannya terhadap kejadian miopia. Miopia sering terjadi pada anak yang ayahnya, ibu atau saudara kandungnya memiliki riwayat miopia. Anak-anak dengan riwayat orang tua yang mengalami miopia cenderung memiliki risiko yang lebih besar untuk terjadinya miopia daripada anak-anak dengan orang tua tanpa miopia.

2. Berdasarkan hasil kajian literatur dari beberapa jurnal dan hasil penelitian, ditemukan bahwa keluarga yang memiliki riwayat yang berhubungan dengan kelainan miopia, maka anak mereka akan mengalami kelainan miopia juga. Dalam hal ini faktor genetik/herediter memiliki pengaruh terhadap pewarisan miopia.

\section{DAFTAR PUSTAKA}

Arikunto. (2006). Prosedur Penelitian Suatu Pendekatan PraktekAnung Inggito

Maksus, (2016) Standar Prosedur Pemeriksaan Refraksi untuk Refraksionis Optisien (Diploma Optometris)

Badan Pusat Statistik, (2013) Statistik IndonesiaDirektorat Pendidikan Luar Biasa, (2006). (Accessed on April, 2013) 
Goss D. (2006). Care of the patient with miopia. Amerika Optometric Association

Grosvendor Theodore (2007) Primary Care Optometry. Elsevier Inc.

Hutahuruk M. Hubungan antara pengetahuan dengan sikap orang tua tentang kelainan refraksi pada anak. Semarang: FK Universitas Diponogoro; 2009.

Haug Sara, Bhisitkul Robert. (2012). Risk factors for retinal detachement following cataract surgery.

Ilyas, Sidharta, dkk. (2001). Penuntun Ilmu Penyakit Mata. Jakarta: Balai Penerbit Fakultas Kedokteran Universitas Indonesia.

Ilyas, Sidharta, dkk (2012). Dasar Teknik Pemeriksaan Dalam Ilmu Penyakit Mata

Ilyas, Sidharta, dkk (2013). Kedaruratan dalam Ilmu Penyakit Mata.

Ilyas, Sidharta, dkk. (2007). Sari Ilmu Penyakit Mata. Jakarta: Balai Penerbit Fakultas Kedokteran Universitas Indonesia.

Mansjoer, A. (2002). Askariasis. Dalam: Kapita Selekta Kedokteran. Jilid 1, Edisi 3. Jakarta: Media Aesculapius FKUI. Halaman: 416 - 418.

Notoatmojo, Soekidjo (2002). Metodologi Penelitian Kesehatan, Rineka Cipta, Jakarta.

Notoatmojo, Soekidjo (2010) Ilmu Perilaku Kesehatan.

Notoatmojo, Soekidjo (2012). Metodologi Penelitian KesehatanNear work activity and miopia in rural and urban schoolchildren in China. Journal Pediatric Ophthalmology Strabismus;

Rudnicka AR， dkk (2016) Global variations and time trends in the prevalence of childhood miiopia, a systematic review and quantitative meta-analysis; Implications for actiology and carly prevention. British journal of Ophtalmology.

Sugiyono, (2008). Metode Penelitian Kuantitatif Kualitatif dan R\&D Bandung: ALFABETA.

Saw S, dkk. (1996) Epidemiology of Miopia

Sepnita, Efhandi Nukman, Eka Bebasari. (Oktober 2014) Hubungan Antara Faktor keturunan, aktivitas melihat dekat dan sikap pencegahan mahasiswa fakultas kedokteran Universitas Riau terhadap kejadian miopia.

Damian Czepita, Mojsa Artur, Maria Ustianowska, Czepita Maciej, Lachowicz Ewelina. (29 Mei 2014) Efek faktor genetik pada terjadinya miopia.

Kattankulathur-603203, Tamil Nadu, India premaguhan (July 2017) Penyebab faktor kesalahan bias pada anakanak: keturunan atau lingkungan.

Mohamed Dirani,Matthew Chamberlain, Sri N. Shekar, Amirul FM Islam,. Pam Garoufalis, Christine Y. Chen, Robyn H. Guymer, dan Paul N. Baird. (November 2005) "Heritabilitas galat Refraktif dan Biometik Mata : Studi Kembar Gen dalam Miopia (GEM)"

Fatika Sari Hasibuan (Juli 2017) "Hubungan Antara Faktor keturunan, aktivitas melihat dekat dan sikap pencegahan mahasiswa fakultas kedokteran Universitas Riau terhadap kejadian miopia"

Kattankulathur, Tamil Nadu,India premaguhan (Desember, 2011) "Penyebab faktor kesalahan biaspada anak-anak: keturunan atau lingkungan" 